\title{
PEMBELAJARAN MATEMATIKA HUMANIS DENGAN METAPHORICAL THINKING UNTUK MENINGKATKAN KEPERCAYAAN DIRI SISWA
}

Oleh:

Heris Hendriana

Program Studi Pendidikan Matematika

STKIP Siliwangi Bandung

\begin{abstract}
Abstrak
Penelitian ini menggunakan metoda eksperimen pre-test postest disign. Tujuan dari penelitian ini adalah untuk mengetahui peningkatan kepercayaan diri siswa dalam matematika pada pembelajaran matematika humanis dengan metaphorical thinking. Penelitian ini dilakukan di tingkat Sekolah Menengah Pertama. Instrumen yang digunakan dalam penelitian ini adalah tes hasil belajar dan angket tentang kepercayaan diri siswa. Hasil penelitian menunjukkan bahwa Matematika humanis dengan metaphorical thinking (MT) lebih unggul dari pembelajaran konvensional dalam meningkatkan kepercayaan diri siswa, baik ditinjau secara keseluruhan maupun berdasarkan level sekolah dan kemampuan awal matematika siswa. Terdapat asosiasi yang tinggi antara KAM dan kepercayaan diri pada kelas dengan pembelajaran metaphorical thinking, dan pada kelas konvensional asosiasi antara KAM dan kepercayaan diri tergolong cukup. Kepercayaan diri siswa yang pembelajarannya menggunakan pendekatan metaphorical thinking (MT) lebih baik daripada yang menggunakan cara biasa (CB), kepercayaan diri siswa yang memperoleh pembelajaran dengan pendekatan MT dan CB berada dalam kualifikasi sedang
\end{abstract}

Kata kunci : metaphorical thinking, kepercayaan diri

\section{Pendahuluan}

Sebagai ilmu pengetahuan yang diperoleh dari hasil pemikiran manusia yang diproses dalam dunia rasio, diolah secara analisis dan sintesis dengan penalaran di dalam struktur kognitif, matematika yang diajarkan di sekolah diharapkan dapat menjadi sarana bagi siswa untuk mengasah kepercayaan diri dalam menghadapi berbagai situasi masalah. Walaupun demikian, sejumlah pendapat yang sering kita dengar tentang matematika adalah menakutkan, membosankan, membingungkan, menyebalkan dll, menjadikan anggapan sebagian orang bahwa matematika malah membuat siswa menjadi tidak percaya diri. Bahkan beberapa mahasiswa di perguruan tinggi yang mengambil 
program studi di luar program studi matematika ketika dihadapkan dengan mata kuliah pengenalan statistik (sebagai mata kuliah wajib) merasa tersiksa dengan hitungan-hitungan yang diberikan.

Pendapat di atas semakin dipertajam dengan model pembelajaran matematika di SD, SMP maupun SMA yang terjadi saat ini cenderung pada pencapaian target materi yang diamanatkan dalam kurikulum atau merujuk pada buku yang dipakai sebagai buku wajib dengan berorientasi pada soal-soal ujian nasional dan seleksi masuk perguruan tinggi pada tahun-tahun sebelumnya, bukan pada pemahaman (understanding) bahan materi yang dipelajari. Para siswa cenderung menghafalkan konsep-konsep matematika, seringkali dengan mengulang-ulang menyebutkan definisi yang diberikan guru atau yang tertulis dalam buku, tanpa berusaha untuk memahami maksud dan isinya.

Selama ini (mudahan-mudahan segera berakhir), memang Hal yang demikian dapat kita amati ketika siswa belajar, kebanyakan belajar baru dilakukan sangat intens atau yang biasa dikenal dengan sebutan SKS (Sistem Kebut Semalam, Sejam, Setengah jam, Semenit, atau ...) menjelang ulangan atau ujian. Anehnya, seorang guru mengatakan bahwa dalam tingkat SMA yang penting adalah bahwa siswa mampu menghafalkan konsep-konsep dan bisa mengerjakan soal-soal seperti soal-soal Ujian Nasional (UN) dan Seleksi Nasional Masuk Perguruan Tinggi Negeri (SNMPTN), hanya dengan satu tujuan, yakni agar mereka bisa lulus UN dan dapat diterima di perguruan tinggi negeri yang dicita-citakan. Sedangkan, terkait pemahaman materi itu nanti dapat dilaksanakan setelah mereka menempuh proses perkuliahan di perguruan tinggi. (Marpaung, 2003:240).

Studi awal yang dilakukan oleh salah seorang guru matematika di SMAN 23 Bandung menunjukkan bahwa guru berperan dalam memberikan stimulus kepada siswa untuk menyenangi belajar matematika. Siswa cenderung memilih guru matematika yang memberikan kesempatan kepada mereka untuk mengeksploitasi ketidakpahamannya terhadap substansi bidang studi matematika. Kesabaran dan kedekatan guru dengan siswa sangat mempengaruhi keberhasilan belajar matematika siswa.

Menghadapi kondisi itu, pembelajaran matematika harus mengubah citra dari pembelajaran yang mekanistis menjadi humanistik yang menyenangkan. Pembelajaran yang dulunya memasung kreativitas siswa menjadi yang membuka kran kreativitas. Pembelajaran yang dulu berkutat pada aspek kognitif menjadi yang berkubang pada semua aspek termasuk kepribadian (Siswono, 2007) 
Pembelajaran matematika harus memperhatikan aspek kemampuan dasar siswa. Kemampuan dasar siswa ini dapat dilihat dari persepsi siswa tentang suatu objek matematika. Pada siswa-siswa tingkat dasar, biasanya persepsi siswa pada suatu objek matematika (pokok bahasan) merupakan modal awal pemahaman dia pada kemampuan matematika lanjutan.

Hasil studi Carreira, S (2001:56) mengatakan bahwa penerapan masalah matematika dalam fenomena nyata memberikan kondisi tersendiri untuk menghasilkan makna dan pengertian dalam konsep matematika tersebut. Ruseffendi (1991:172) pemahaman konsep akan lebih baik jika dikaitkan dengan keadaan lain (domain lain).

Selanjutnya, Carreira, S (2001: 262) memberikan gambaran bahwa menemukan hubungan antara matematika dan fenomena nyata adalah sebuah proses dan usaha memainkan model yang penting. Ini dikarenakan model matematika merupakan rangkuman sejumlah konsep matematika dan rangkuman sejumlah interpretasi yang memerlukan interpretasi yang akurat. Perlu proses yang integrative antara model dan aplikasi matematika dalam pembelajarannya di kelas. Seluruh aktivitas diharapkan mempunyai pengaruh positif pada belajar matematika sehingga belajar matematika menjadi bermakna.

Membuat matematika yang humanis dalam pembelajarannya merupakan modal awal untuk memberikan stimulus sejak dini kepada siswa sehingga tanggapan negatif terhadap matematika berkurang. Dengan menyenangi matematika, belajar matematika menjadi sebuah kebanggaan bagi siswa sehingga diharapkan kebiasaan berpikir kreatif menjadi terlatih. Salah satu alternatif pendekatan pembelajaran yang diharapkan mendukung matematika yang huanis dan kreatifitas siswa diantaranya adalah Pendekatan Metaphorical Thinnking. Penulis mencoba meneliti tentang penerapan pendekatan metaphorical thinking ini pada peningkatan daya kreatifitas siswa.

Selain variabel pembelajaran, berdasarkan salah satu karakteristik matematik sebagai ilmu yang sistimatik dan terstruktur maka diperkirakan bahwa variabel kluster sekolah, dan kemampuan awal matematika siswa juga berperan dalam pencapaian kemampuan kreativitas matematik siswa. Analisis di atas mendorong dilakukannya studi untuk menjawab permasalahan sebagai berikut.

1. Bagaimana kualitas kepercayaan diri siswa setelah pembelajaran ditinjau secara keseluruhan dan berdasarkan level sekolah dan tingkat kemampuan awal matematik siswa?

2. Adakah asosiasi di antara variabel-variabel kepercayaan diri siswa, dan kemampuan awal matematika? 


\section{Landasan Teori}

\section{Kepercayaan diri}

Kepercayaan diri atau keyakinan diri diartikan sebagai suatu kepercayaan terhadap diri sendiri yang dimiliki setiap individu dalam kehidupannya, serta bagaimana individu tersebut memandang dirinya secara utuh dengan mengacu pada konsep diri (Rakhmat, 2000). Lauster (Fasikhah, 1994), menyatakan bahwa kepercayaan diri merupakan suatu sikap atau perasaan yakin atas kemampuan diri sendiri sehingga orang yang bersangkutan tidak terlalu cemas dalam tindakan-tindakannya, dapat merasa bebas untuk melakukan hal - hal yang disukainya dan bertanggung jawab atas perbuatannya, hangat dan sopan dalam berinteraksi dengan orang lain, dapat menerima dan menghargai orang lain, memiliki dorongan untuk berprestasi serta dapat mengenal kelebihan dan kekurangannya.

Kepercayaan diri akan memperkuat motivasi mencapai keberhasilan, karena semakin tinggi kepercayaan terhadap kemampuan diri sendiri, semakin kuat pula semangat untuk menyelesaikan pekerjaannya. Kemauannya untuk mencapai apa yang menjadi sasaran tugas juga akan lebih kuat. Berarti ia juga mempunyai komitmen kuat untuk bekerja dengan baik, supaya penyelesaian pekerjaannya berjalan dengan sempurna. Dibandingkan dengan orang lain, biasanya orang semacam ini juga akan lebih cepat menyelesaikan pekerjaannya dan lebih mudah menerima pandangan yang berbeda dengan sudut pandang dirinya. Orang yang selalu curiga atau tidak dapat menerima pendapat yang berbeda dengan pendapatnya biasanya khawatir pendapatnya akan lebih jelek dari pendapat orang lain.

Menurut Lauster (Fasikhah, 1994), terdapat beberapa karakteristik untuk menilai kepercayaan diri individu, diantaranya: (a) Percaya kepada kemampuan sendiri, yaitu suatu keyakinan atas diri sendiri terhadap segala fenomena yang terjadi yang berhubungan dengan kemampuan individu untuk mengevaluasi serta mengatasi fenomena yang terjadi tersebut, (b) Bertindak mandiri dalam mengambil keputusan, yaitu dapat bertindak dalam mengambil keputusan terhadap apa yang dilakukan secara mandiri tanpa banyak melibatkan orang lain. Selain itu, mempunyai kemampuan untuk meyakini tindakan yang diambilnya tersebut, (c) Memiliki konsep diri yang positif, yaitu adanya penilaian yang baik dari dalam diri sendiri, baik dari pandangan maupun tindakan yang dilakukan yang menimbulkan rasa positif terhadap diri sendiri, (d). Berani mengungkapkan pendapat, yaitu adanya suatu sikap untuk mampu mengutarakan sesuatu dalam diri yang ingin diungkapkan kepada orang lain tanpa adanya paksaan atau hal yang dapat menghambat pengungkapan perasaan tersebut. 


\section{Matematika Humanis}

Pemahaman terhadap matematika yang terbentuk melalui proses asimilasi dan akomodasi itu sungguh bersifat pribadi dan mengakar dalam masing-masing individu siswa. Para siswa akan belajar untuk menghargai dan mencintai matematika karena mereka memiliki keyakinan tentang bagaimana caranya merumuskan dan menggunakan sarana matematika ketika diperlukan. Artinya, ketika proses pembelajaran matematika berlangsung, guru lebih berperan sebagai fasilitator dan moderator, bukan sebagai penceramah atau pengajar, dan para siswa sendirilah yang aktif mencari, menyelidiki, merumuskan, menguji, membuktikan, mengaplikasikan, menjelaskan, dan sebagainya. Sistem belajar siswa aktif memang berorientasi pada siswa dan bukan pada bahan pelajaran, pada proses dan bukan pada hasil pembelajaran. Sehingga, akhirnya para siswa akan menguasai bukan hanya pada materi atau bahan yang dipelajarinya, melainkan juga bagaimana mempelajari materi itu secara bermakna.

Berikut, diberikan 2 contoh kasus proses pembelajaran matematika yang diakomodasi dari Fathani (2010) :

\section{Contoh 1 :}

Seorang guru SD menjelaskan kepada siswanya tentang macam-macam bilangan. Ketika menerangkan bilangan cacah, beliau memberikan definisi bahwa bilangan cacah adalah bilangan yang dimulai dari nol $(0,1,2,3, \ldots)$. Dari penjelasan tersebut siswa hanya akan menangkap pesan bahwa bilangan yang dimulai dari nol dinamakan bilangan cacah, dan tidak mengetahui untuk apa bilangan cacah itu dalam kehidupan, kecuali siswa yang berusaha untuk mencari jawabannya.

\section{Contoh 2 :}

Sorang guru bermaksud menjelasan tentang macam-macam bilangan dengan berusaha menjelaskan bagaimana bilangan-bilangan itu digunakan dalam kehidupan sehari-hari. "Bilangan cacah dijelaskan, bahwa bilangan cacah adalah bilangan yang dimulai dari nol yang jika kita amati dalam kehidupan, bilangan cacah ini digunakan untuk menyatakan jumlah objek atau barang". Kata guru ketika menjelaskan. Lalu ada salah satu siswa yang bertanya, "Kalau begitu, berarti ada objek yang jumlahnya nol, bu?". Kemudian guru tersebut mengajak para siswa untuk ke halaman sekolah. Guru tersebut bertanya: "Berapa banyak sepeda yang diparkir di halaman sekolah ini?". Dengan serentak siswa menjawab: "ada sepuluh buah sepeda, bu". Selanjutnya guru tersebut bertanya lagi, "Berapa jumlah mobil yang diparkir di halaman sekolah ini?". "Tidak ada , Bu". Jawab siswa serempak. Dari jawaban inilah, kemudian guru menjelsakan bahwa ada objek yang berjumlah nol, dalam hal ini jumlah 
mobil yang di parkir di halam sekolah. Nol adalah bilangan cacah yang dapat digunakan untuk menyatakan jumlah obyek kosong atau tidak ada.

Sriyanto, HJ. (Fathani, 2004) berpendapat, bahwa seorang guru yang mampu menghadirkan diri sebagai sosok teman yang akrab, familiar, mau terbuka untuk mendengarkan, dan membantu setiap kesulitan yang dihadapi siswa kiranya akan mudah diterima oleh siswa daripada guru yang menampilkan diri sebagai sosok yang galak, seram menakutkan, dan sering menghukum siswa. Kedekatan secara personal antara guru dan siswa akan membuat siswa lebih terbuka mengungkapkan kesulitan dan persoalan yang dihadapinya dalam pembelajaran matematika sehingga guru juga akan lebih mudah untuk membantu mencari solusi yang tepat.

Ciri-ciri manusiawi matematika hanya dapat dialami dan diapresiasi oleh para siswa kalau mereka mempelajari matematika itu juga secara manusiawi, yaitu dengan membangun sendiri pemahaman mereka akan unsur-unsur matematika. Pemahaman tersebut dapat terbentuk bukan dengan menerima apa saja yang diajarkan dan mengahafalkan rumus-rumus dan langkah-langkah yang diberikan, melainkan dengan membangun makna dari apa yang dipelajari dengan mempergunakan informasi baru yang mereka peroleh untuk mengubah, melengkapi atau menyempurnakan pemahaman yang telah tertanam sebelumnya, dengan memanfaatkan keleluasaan yang tersedia untuk melakukan eksperimen, termasuk di dalamnya kemungkinan untuk berbuat kesalahan dan belajar dari kesalahan tersebut.

\section{Metaphorical Thinking}

Berpikir metaforik adalah proses berpikir yang menggunakan metaforametafora untuk memahami suatu konsep. Menurut Holyoak \& Thagard (1995), metafora berawal dari suatu konsep yang diketahui siswa menuju konsep lain yang belum diketahui atau sedang dipelajari siswa. Metafora tergantung kepada sejumlah sifat dari konsep dan benda yang dimetaforkan.

Berpikir metaforik dalam matematika digunakan untuk memperjelas jalan pikiran seseorang yang dihubungkan dengan aktivitas matematiknya. Konsep-konsep abstrak yang diorganisasikan melalui berpikir metaforik, dinyatakan dalam hal-hal kongkrit berdasarkan struktur dan cara-cara bernalar yang didasarkan sistem sensori-motor yang disebut dengan konseptual metafor. Bentuk konseptual metafor meliputi:

a. Grounding methapors merupakan dasar untuk memahami ide-ide matematika yang dihubungkan dengan pengalaman sehari-hari.

b. Linking methapors : membangun keterkaitan antara dua hal yaitu memilih, menegaskan, memberi kebebasan, dan mengorganisasikan karakteristik 
dari topik utama dengan didukung oleh topik tambahan dalam bentuk pernyataan-pernyataan metaforik.

c. Redefinitional methapors: Mendefinisikan kembali metafor-metafor tersebut dan memilih yang paling cocok dengan topik yang akan diajarkan.

Berpikir metaforik dalam matematika dimulai dengan memodelkan suatu situasi secara matematis, kemudian model-model itu dimaknai dengan pendekatan dari sudut pandang semantik. Di dalam pembelajaran matematika penggunaan metafora oleh siswa merupakan suatu cara untuk menghubungkan konsep-konsep matematika dengan konsep-konsep yang telah dikenal siswa dalam kehidupan sehari-hari, dimana dia mengungkapkan konsep matematika dengan bahasanya sendiri yang menunjukkan pemahaman siswa terhadap konsep tersebut.

Berdasarkan seluruh uraian di atas maka berpikir metaforik dalam penelitian ini didefinisikan sebagai suatu proses berpikir untuk memahami dan mengkomunikasikan konsep-konsep abstrak dalam matematika menjadi hal yang lebih konkrit dengan membandingkan 2 hal yang berbeda makna.

Berpikir metaforik matematik berbeda dengan berpikir metaforik biasa, perbedaannnya terletak pada pemahaman konsep dan aplikasi dalam menyelesaikan persoalan yang harus dihadapi. Sebagai ilustrasi berikut diberikan contoh perbedaan berpikir metaforik dalam matematika dan metaforik biasa:

a. Metaphora matematika

Ruas garis AC panjangnya $20 \mathrm{~cm}$. Titik B terletak pada ruas garis AC. Bentuklah persegi ABGF dan BCDE, dengan mempertimbangkan keliling dari bangun yang dibentuk dari dua persegi tersebut (ABCDEGF). Jika posisi B berubah bagaimana dengan perubahan kelilingnya ?

Dalam menyelesaikan soal ini metaphorical thinking siswa dapat dilihat dalam merepresentasikan titik statis B yang bergerak pada segmen AC, dimana ia menggerakkan jari-jari tangannya dari kiri ke kanan atau sebaliknya untuk menunjukkan rangkaian pergeseran titik B pada segmen AC. Kemudian ia menyatakan simbol pergeseran tadi dalam sebuah variabel $\mathrm{k}$ sehingga pada akhirnya diperoleh suatu fungsi yang menyatakan hubungan antara perubahan nilai k dengan keliling bangun ABCDEGF.

\section{b. Metaphora Biasa}

Shakespeare dalam bukunya menulis bahwa Juliet itu seperti matahari bagi Romeo, karena Juliet itu begitu sentral dan amat penting dalam kehidupan Romeo. Metaphora yang dilakukan Shakespeare terhadap Juliet hanya sebatas 
untuk menggambarkan sosok Juliet. Lain halnya dengan penggambaran siswa dalam menunjukkan rangkaian pergeseran titik B dengan jari tangannya adalah untuk mengaplikasikan konsep matematika dan mencari solusi dari masalah matematika yang diberikan.

\section{Metode dan Disain Penelitian}

Penelitian ini merupakan suatu eksperimen pre test - post test yang menerapkan pendekatan metaphorical thinking untuk mengembangankan kemampuan pemahaman dan kreativitas matematik siswa SMP dengan disain sebagai berikut :

$$
\begin{array}{ccc}
0 & X & 0 \\
0 & & 0
\end{array}
$$

Keterangan :

A : Pemilihan sampel tiga SMP secara acak masing-masing satu SMP dari tiap kelompok level sekolah (tinggi, menengah, dan rendah). Pada SMP terpilih ditetapkan dua kelas (kelas 7) secara acak dari kelas 7 yang ada.

0 : Tes awal dan tes akhir hasil belajar matmatika siswa.

$\mathrm{X}$ : Pembelajaran dengan menggunakan pendekatan Metaphorical thinking

Dengan demikian subyek penelitian ini adalah sebanyak 237 orang siswa yang tersebar padas enam (6) kelas 7 dari tiga (3) SMP yang terpilih. Sebelum pembelajaran, selain diberikan tes awal kemampuan pemahaman dan komunikasi matematik, siswa pada tiap kelas juga di kelompokkan dalam tiga klasifikasi (tinggi, menengah, dan rendah) berdasarkan kemampuan awal matematika prasyarat dengan menggunakan aturan patokan. Kemampuan awal matematika prasyarat diestimasi melalui tes materi prasyarat dari materi yang akan diajarkan.

\section{Temuan dan Pembahasan}

\section{Kepercayaan Diri Siswa}

Temuan tentang kepercayaan diri siswa secara keseluruhan dan berdasarkan pendekatan pembelajaran (MT dan konvensional), peringkat sekolah (tinggi, sedang dan rendah), dan kemampuan awal matematika siswa (KAM) kelompok baik, sedang atau kurang tersaji pada Tabel 1. 
Tabel 1

Kepercayaan Diri Siswa berdasarkan Pendekatan Pembelajaran, Peringkat Sekolah, dan KAM

\begin{tabular}{|c|c|c|c|c|c|c|c|c|c|c|}
\hline \multirow{3}{*}{$\begin{array}{c}\text { Level } \\
\text { Sekolah }\end{array}$} & \multirow{3}{*}{ KAM } & \multicolumn{6}{|c|}{ Pendekatan pembelajaran } & \multirow{2}{*}{\multicolumn{3}{|c|}{ Total }} \\
\hline & & & $M T$ & & & vensio & & & & \\
\hline & & Rerata & $S D$ & $N$ & Rerata & $S D$ & $N$ & Rerata & $S D$ & $N$ \\
\hline \multirow{4}{*}{ Tinggi } & Baik & 169,36 & 12,68 & 14 & 151,75 & 8,92 & 12 & 161,23 & 14 & 26 \\
\hline & Sedang & 147,38 & 4,7 & 13 & 130,86 & 5,56 & 14 & 138,82 & 9,82 & 27 \\
\hline & Kurang & 113,85 & 12,52 & 13 & 112 & 9,33 & 13 & 112,92 & 10,86 & 26 \\
\hline & Sub total & 144,18 & 25,49 & 40 & 131 & 17,90 & 39 & 137,67 & 22,88 & 79 \\
\hline \multirow{4}{*}{ Sedang } & Baik & 176,12 & 10,33 & 8 & 159,14 & 13,23 & 7 & 168,2 & 14,33 & 15 \\
\hline & Sedang & 153,65 & 5,18 & 17 & 134,84 & 8,01 & 19 & 143,72 & 11,66 & 36 \\
\hline & Kurang & 126 & 13,37 & 13 & 110,64 & 11,5 & 14 & 118,04 & 14,17 & 27 \\
\hline & Sub total & 148,92 & 20,94 & 38 & 130,62 & 19,96 & 40 & 139,54 & 22,3 & 78 \\
\hline \multirow{4}{*}{ Rendah } & Baik & 186 & 3,61 & 3 & 171,67 & 15,54 & 3 & 178,83 & 12,78 & 6 \\
\hline & Sedang & 154,48 & 10,34 & 21 & 140,7 & 9 & 20 & 147,76 & 11,86 & 41 \\
\hline & Kurang & 112,19 & 12,98 & 16 & 113,76 & 10,70 & 17 & 113 & 11,70 & 33 \\
\hline & Sub total & 139,92 & 26,71 & 40 & 131,58 & 20,09 & 40 & 135,75 & 23,85 & 80 \\
\hline \multirow{4}{*}{ Total } & Baik & 173,52 & 12,29 & 25 & 156,82 & 12,76 & 22 & 165,70 & 14,97 & 47 \\
\hline & Sedang & 152,39 & 8,10 & 51 & 112,25 & 10,42 & 44 & 144,04 & 11,74 & 104 \\
\hline & Kurang & 116,98 & 13,86 & 42 & 136 & 8,70 & 53 & 114,56 & 12,38 & 86 \\
\hline & Total & 144,26 & 24,60 & 118 & 131,07 & 19,20 & 119 & 137,64 & 22,98 & 237 \\
\hline
\end{tabular}

Keterangan: Skor maksimum ideal 200

Berdasarkan Tabel 1, dapat dikemukakan deskripsi kepercayaan diri siswa sebagai berikut:

1) Secara keseluruhan rata-rata kepercayaan diri siswa adalah 137,64 (dari skor maksimum ideal 200). Hal ini menunjukkan bahwa kepercayaan diri siswa secara keseluruhan termasuk kategori sedang.

2) Kepercayaaan diri siswa berdasarkan jenis pendekatan pembelajaran (MT dan CB) berturut-turut ditemukan sebesar 144,26 dan 131,07; dengan simpangan baku 24,60 dan 19,20; dan jumlah siswa 118 dan 119. Pada sekolah level tinggi tinggi berturut ditemukan sebesar 144,18 dan 131 dengan simpangan baku 25,49 dan 17,9; dan jumlah siswa 40 dan 39. Pada sekolah level sedang ditemukan berturutturut sebesar 148,92 dan 130,62; simpangan baku 20,94 dan 19,96; dan jumlah siswa 38 dan 40. Pada sekolah level rendah ditemukan 139,92 dan 131,58; simpangan baku 26,71 dan 20,09; dan jumlah siswa 40 dan 40. Temuan ini menunjukkan bahwa metaphorical thinking lebih unggul dari pada pembelajaran konvensional dalam mengembangkan kepercayaan diri siswa

3) Kepercayaan diri siswa berdasarkan peringkat sekolah (tinggi, sedang dan rendah) berturut-turut ditemukan sebesar 137,$67 ; 139,54$ dan 135,75 dengan simpangan baku 22,88; 22,3; 23,85; dan jumlah siswa 79, 78 dan 80 . Temuan ini 
menunjukkan bahwa pengklusteran level sekolah yang dibuat oleh dinas pendidikan setempat tdak merupakan prediktor bagi pencapaian kepercayaan diri siswa.

4) Kepercayaan diri siswa berdasarkan KAM (baik, sedang dan kurang) berturut adalah sebesar 165,70 , 144,04, dan 114,56; dengan simpangan baku 14.97, 11,74, dan 12,38; dan jumlah siswa 47,104, dan 86. Pada pembelajaran MT dan konvensional untuk siswa dengan KAM tinggi berturut-turut ditemukan 173,52 dan 156,82 dengan simpangan baku 12,29 dan 12,76 dan jumlah siswa 25 dan 22. Untuk siswa dengan KAM sedang ditemukan berturut-turut sebesar 152,39 dan 112,25 dengan simpangan baku 8,10 dan 10,42 dan jumlah siswa 51 dan 44. Sedang untuk siswa dengan KAM rendah ditemukan 116,98 dan 136 dengan simpangan baku 13,86 dan 8,70 dan jumlah siswa 42 dan 53. Dari temuan di atas, secara keseluruhan, pada KAM tinggi dan sedang kepercayaan diri siswa yang memperoleh pembelajaran MT lebih baik dari yang mendapat pembelajaran konvwensional. Namun pada siswa dengan KAM rendah kondisi tersebut tidak ditemukan. Temuan ini menunjukkan bahwa keunggulan metaphorical thinking dari pembelajaran biasa lebih sesuai untuk siswa dengan KAM tinggi dan sedang, dan untuk siswa dengan KAM rendah lebih baik dengan pembelajaran konvensional.

5) Dengan demikian dari ketiga variabel yaitu level sekolah, KAM, dan pendekatan pembelajaran maka variabel pendekatan pembelajaran (Metaphorical thinking) yang paling berperan dalam pencapaian kepercayaan diri siswa.

\section{Asosiasi antara Kemampuan Awal Matematik (KAM) dan Kreativitas Matematik Siswa}

Analisis asosiasi antara kemampuan awal matematik (KAM) dan kreativitas matematik siswa tersaji pada Tabel 2 .

Tabel 2

Banyaknya Siswa Berdasarkan Kualitas KAM dan Kreativitas matematik Siswa

\begin{tabular}{|c|c|c|c|c|}
\hline \multirow{2}{*}{ KAM } & \multicolumn{3}{|c|}{ Komunikasi Matematik } & \multirow{2}{*}{ Jumlah } \\
\cline { 2 - 4 } & Kurang & Sedang & Baik & \\
\hline Kurang & 81 & 5 & 0 & 86 \\
\hline Sedang & 9 & 93 & 3 & 105 \\
\hline Baik & 0 & 10 & 36 & 46 \\
\hline JUMLAH & 90 & 108 & 39 & 237 \\
\hline
\end{tabular}


Dari hasil perhitungan diperoleh $\chi^{2}{ }_{\text {hit }}=323,83$ dengan $\alpha=0,05$ dan $\mathrm{dk}=(3-1)$ (3-1)=4 didapat $\chi_{\text {tab }}^{2}=9,49$, sehingga dapat disimpulkan terdapat asosiasi yang signifikan antara KAM dan kemampuan kreativitas matematik siswa. Selanjutnya untuk mengetahui derajat asosiasi (ketergantungan) antara variabel yang satu dengan yang lainnya digunakan koefisien kontingensi C. Dari hasil perhitungan diperoleh $\mathrm{C}=0,76$ dan $\mathrm{C}_{\text {maks }}=0,816$, sehingga diperoleh $\mathrm{C}=$ $0,93 \mathrm{C}_{\text {maks }}$ yang termasuk ke dalam kriteria tinggi.

\section{Asosiasi antara KAM dan Kepercayaan Diri}

Analsis asosiasi antara kemampuan pemahaman matematik dan kreativitas matematik siswa tersaji pada Tabel 3.

Tabel 3

\section{Banyaknya Siswa Berdasarkan KAM dan Kepercayaan Diri pada Kelas Eksperimen}

\begin{tabular}{|c|c|c|c|c|}
\hline \multirow{2}{*}{ KAM } & \multicolumn{3}{|c|}{ Kepercayaan Diri } & \multirow{2}{*}{ Jumlah } \\
\cline { 2 - 4 } & Kurang & Sedang & Baik & \\
\hline Kurang & 16 & 26 & 0 & 42 \\
\hline Sedang & 0 & 40 & 11 & 51 \\
\hline Baik & 0 & 3 & 22 & 25 \\
\hline JUMLAH & 16 & 69 & 33 & 118 \\
\hline
\end{tabular}

Dari hasil perhitungan diperoleh $\chi^{2}{ }_{h i t}=86,46$ dengan $\alpha=0,05$ dan $\mathrm{dk}=$ (31)(3-1) $=4$ didapat $\chi_{\text {tab }}^{2}=9,49$, sehingga dapat disimpulkan terdapat asosiasi yang signifikan antara KAM dan kepercayaan diri siswa. Selanjutnya untuk mengetahui derajat asosiasi (ketergantungan) antara variabel yang satu dengan yang lainnya digunakan koefisien kontingensi $C$. Dari hasil perhitungan diperoleh $\mathrm{C}=0,65$ dan $\mathrm{C}_{\text {maks }}=0,816$, sehingga diperoleh $\mathrm{C}=0,80 \mathrm{C}_{\text {maks }}$ yang termasuk ke dalam kriteria tinggi.

Untuk melihat ada tidaknya hubungan antara kepercayaan diri siswa dan KAM untuk kelas kontrol, hasil penggolongannya disajikan dalam Tabel 4. 
Tabel 4

Banyaknya Siswa Berdasarkan KAM dan Kepercayaan Diri Pada Kelas Konvensional

\begin{tabular}{|c|c|c|c|c|}
\hline \multirow{2}{*}{ KAM } & \multicolumn{3}{|c|}{ Kepercayaan Diri } & \multirow{2}{*}{ Jumlah } \\
\cline { 2 - 4 } & Kurang & Sedang & Baik & \\
\hline Kurang & 16 & 28 & 0 & 44 \\
\hline Sedang & 0 & 53 & 0 & 53 \\
\hline Baik & 0 & 16 & 6 & 22 \\
\hline JUMLAH & 16 & 97 & 6 & 119 \\
\hline
\end{tabular}

Dari hasil perhitungan diperoleh $\chi^{2}{ }_{h i t}=57,88$ dengan $\alpha=0,05$ dan $\mathrm{dk}=(3-$ 1)(3-1) $=4$ didapat $\chi_{\text {tab }}^{2}=9,49$, sehingga dapat disimpulkan terdapat asosiasi yang signifikan antara KAM dan kepercayaan diri siswa. Selanjutnya untuk mengetahui derajat asosiasi (ketergantungan) antara variabel yang satu dengan yang lainnya digunakan koefisien kontingensi $C$. Dari hasil perhitungan diperoleh $\mathrm{C}=0,33$ dan $\mathrm{C}_{\text {maks }}=0,816$, sehingga diperoleh $\mathrm{C}=0,33 \mathrm{C}_{\text {maks }}$ yang termasuk ke dalam kriteria cukup.

\section{Pembahasan}

Dari hasil analisis data terhadap kepercayaan diri siswa diperoleh kesimpulan bahwa tingkat kepercayaan diri siswa yang memperoleh pembelajaran dengan pendekatan MT lebih baik daripada siswa yang memperoleh pembelajaran dengan cara biasa. Hasil ini sejalan dengan pandangan konstrukstivisme yang mengatakan bahwa pengetahuan dalam diri seseorang terbentuk ketika seseorang mengalami tempaan kognitif. Melalui pendekatan MT belajar dapat dipahami sebagai proses kognitif yang bergulir dengan sendirinya dalam diri seseorang ketika yang bersangkutan memperoleh pengalaman kongkrit, wacana kolaboratif, dan kegiatan melakukan refleksi. Selain itu dalam pendekatan ini konsep baru yang akan dipelajari siswa dibandingkan dengan konsep-konsep yang sudah ada dalam struktur kognitif siswa, sehingga terjadi belajar bermakna. Dalam pendekatan ini pula siswa diberi kesempatan bereksplorasi dengan berbagai metafora untuk mengungkapkan pemahamannya terhadap suatu konsep dan diberi kebebasan yang seluasluasnya untuk berani mengemukakan pendapatnya. Karena siswa terus dilatih 
bereksplorasi dan berani mengemukakan pendapat serta dia merasa belajarnya bermakna maka siswa akan lebih percaya diri dalam belajar matematika.

Kesempatan untuk bereksplorasi dan berani mengemukakan pendapat juga membuat siswa dengan KAM kurang menjadi lebih percaya diri dalam belajar matematika. Hal ini terbukti dari hasil analisis data bahwa terdapat asosiasi yang tinggi antara KAM dan kepercayaan diri siswa, dimana siswa KAM baik, kepercayaan dirinya cenderung baik, siswa KAM sedang kepercayaan dirinya scenderung sedang, tetapi yang menarik siswa KAM kurang kepercayaan dirinya cenderung sedang. Fenomena pada siswa KAM kurang ini

\section{Kesimpulan}

Berdasarkan analisis data dan pembahasan yang telah dikemukakan pada bab sebelumnya, diperoleh beberapa kesimpulan sebagai berikut:

1. Kepercayaan diri siswa yang pembelajarannya menggunakan pendekatan metaphorical thinking (MT) lebih baik daripada yang menggunakan cara biasa (CB), kepercayaan diri siswa yang memperoleh pembelajaran dengan pendekatan MT dan CB berada dalam kualifikasi sedang.

2. Terdapat asosiasi yang tinggi antara KAM dan kepercayaan diri pada kelas dengan pembelajaran metaphorical thinking, dan pada kelas konvensional asosiasi antara KAM dan kepercayaan diri tergolong cukup.

\section{DAFTAR PUSTAKA}

Carreira, S. (2001). Where There's a Model, There's a Metaphor: Metaphorical Thinking in Students' Understanding of a Mathematical Model. An International Journal Mathematical Thinking and Learning. 3(4), 261-287

Fathani, A.H. (2010). Pembelajaran Matematika yang Humanis. [Online]. Tersedia:

http://yppti.org/index.php?option=com_content\&view=article\&id=3 65:pembelajaran-matematika-yanghumanis\&catid=5:artikel\&Itemid $=4$.

Fasikhah, S.S. 1994. Peranan Kompetensi Sosial Pada T.L Koping Remaja Akhir. Tesis. Yogyakarta. Program P.S UGM Yogyakarta.

Holyoak, KJ, \& Thagard, P. (1995). Mental leaps: Analogy in creative thought . Cambridge, MA: MIT Press.

Marpaung, Y. 2003, PMRI, Pembelajaran Matematika yang Menyenangkan. Buletin PMRI: halaman 4, Edisi Perdana.

Rakhmat, J. (2000). Psikologi Agama. Jakarta: Raja Grafindo Persada. 
Ruseffendi,E.T.(1991). Pengantar kepada Membantu Guru Mengembangkan Kompetensinya dalam Pengajaran Matematika untuk Meningkatkan CBSA. Bandung: Tarsito

Siswono, Tatag Y. E. 2007. Penjenjangan Kemampuan Berpikir Kreatif dan Identifikasi Tahap Berpikir Kreatif Siswa dalam Memecahkan dan Mengajukan Masalah Matematika. Disertasi Doktoral Program Pasca Sarjana UNESA Surabaya. Tidak dipublikasikan.

Sriyanto (2004). Momok Itu Bernama matematika. Basis (Juli-Agustus 2004) 